\title{
Do (in)traduzível ao transmissível em Freud: um debate em torno do livro "Versões de Freud" de Pedro Heliodoro Tavares.
}

From the (un)translatable to the transmissible in Freud: a debate over the book Versões de Freud, by Pedro Heliodoro Tavares

Maurício Eugênio Maliska

TAVARES, P. H. M. B. Versões de Freud: breve panorama crítico das traduções de sua obra. Rio de Janeiro, 7Letras, 2011.

Acaba de ser lançado o livro Versões de Freud: breve panorama crítico das traduções de sua obra de autoria de Pedro Heliodoro TAVAREs, pela Editora 7 Letras do Rio de Janeiro. A obra surge em um momento muito oportuno do debate brasileiro em torno das traduções de Freud. Assim como faltava uma tradução de Freud direta do alemão para o português, tal como o autor comenta no início de seu livro, pode-se também dizer que no Brasil se carecia de uma obra crítica que ponderasse e orientasse o leitor frente às celeumas e controvérsias das traduções de Freud. O livro de TAVARES (2011) cumpre com esse requisito sem concessões, pois trata-se de uma obra crítica que comenta com muito rigor e critério técnico, conceitual, clínico, linguístico, literário e estilístico as recentes traduções da obra de Freud, não sem antes fazer um panorama mundial e histórico sobre sua obra e suas versões.

Nesse livro, TAVARES (2011) se lança a comentar as três traduções da obra de Freud realizadas do alemão para o português, sem o atravessamento de outras línguas,

\footnotetext{
* Doutor, Universidade do Sul de Santa Catarina (UNISUL). E-mail: mmaliska@ yahoo.com.br
} 
Maliska, M. E. - Do (in)traduzível (resenha)

como ocorreu em traduções anteriores. A partir de 2009, a obra de Freud entrou em domínio público e vimos surgir no Brasil as traduções de Luiz Alberto HANNS (Editora Imago), Paulo César de SouZA (Cia. das Letras) e Renato ZwICK (Editora L\&PM). TAVARES (2011) faz uma análise crítica e criteriosa de cada uma das versões, mostrando suas diferenças, seus pontos fortes e fracos e também comentários sobre as opções dos tradutores frente ao estilo literário, técnico, erudito etc. Esse foco central é introduzido com capítulos que comentam a escrita de Freud, sua intenção em dar um estatuto conceitual às palavras ordinárias da língua alemã, as questões relativas à psicanálise e tradução; também há comentários muito pertinentes sobre as mais influentes traduções estrangeiras da obra de Freud, em especial, as traduções inglesa, francesa e castelhana.

Com uma escrita suave no estilo e densa nos conceitos, TAVARES (2011) nos conduz a várias reflexões clínicas, conceituais, históricas, linguísticas e críticas. Quanto ao aspecto clínico, o livro nos faz pensar a língua para além do idioma, quando toca em certo aspecto intraduzível da alíngua, tal como pensa Roberto HARARI (2004) em seu livro Intraducción del psicoanálisis: acerca de L'insu..., de Lacan (Madrid, Editorial Sintesis). Tomando por base o conceito lacaniano de alíngua [lalangue], o autor mostra que, a rigor, em psicanálise sempre há uma "língua" estrangeira que habita o sujeito e o faz falar, ou seja, o sujeito fala em outra língua, mesmo quando utiliza o seu idioma “materno". Há, no mínimo, duas línguas que falam no sujeito, uma é o idioma e outra a alíngua, enquanto uma lalação do cantarolar materno que constitui o sujeito em seus aspectos psíquicos. A este propósito, HARARI (2008) - na obra: O Psicanalista, o que é isso? (Rio de Janeiro, Cia. de Freud) - sustenta que o sujeito é bífido, pois fala duas línguas, a língua idioma e alíngua própria da sua constituição enquanto sujeito. Esse ponto parece interessante, pois traduzir Freud não é somente uma proposta no campo linguístico, no sentido de trabalhar com certa transposição de uma língua a outra, mas metalinguístico, na medida em que se faz necessário encontrar em outra língua uma forma que dê (parcialmente) conta dessa transposição. Ainda que LACAN (1991: 68) tenha dito, no Séminaire 17, que "não há metalinguagem", o que Freud opera e que é comentado com rigor no livro em destaque é a maneira singular que este ancora linguagem e inconsciente, dando condições para LACAN (1991) mostrar que o inconsciente é estruturado como uma linguagem. Isso faz com que o trabalho de traduzir Freud não se reduza a uma simples passagem de uma língua a outra, mas o quanto há de assimilação da teoria psicanalítica, afinal, como afirma TAVARES (2011: 25): "Freud 
Maliska, M. E. - Do (in)traduzível (resenha)

nunca é difícil de se entender, é certamente difícil de se assimilar e aceitar" e a tradução pode ser fundamental nessa aceitação/assimilação. Por essa via toca-se no ponto de resistência frente à Psicanálise, em que o trabalho de tradução certamente se defronta com as próprias resistências do tradutor à Psicanálise. Essas resistências marcam a (o)posição do tradutor que talvez, mesmo sendo psicanalista, não está isento das resistências, muito pelo contrário, é nesse caso que ela pode tomar corpo e dimensão. FREUD (1914), em A história do movimento psicanalítico, já advertia que a resistência frente à Psicanálise vinha do próprio psicanalista e não de um elemento externo, afinal, a resistência é um mecanismo intrapsíquico, que vem de dentro e não do exterior. Exemplo disso pode ser encontrado no próprio livro em resenha, quando o autor apresenta a lista de estilos de Freud elencada pelos tradutores (psicanalistas) franceses; LAPLANCHE, COTET \& BOURGUignON (apud TAVARES 2011: 29): “o filósofo e didata da metapsicologia; o dialético da Psicologia das Massas; o ensaísta da Recordação de Infância de Leonardo da Vinci; o orador de Recordações atuais sobre a Guerra e a Morte; [...]"; enfim, uma série de estilos que não incluem o Freud psicanalista, que, em minha opinião, é o que mais prepondera em sua obra; nem filósofo, nem dialético, nem ensaísta, nem orador..., mas um psicanalista.

Versões de Freud... também traz um percurso histórico, pois mostra, de certo modo, a história da Psicanálise contada via traduções; uma história que aponta desde as primeiras traduções de Jones e Strachey até a Convergência: movimento lacaniano para a psicanálise freudiana e as Reuniões Lacanoamericanas de Psicanálise - movimentos recentes da Psicanálise atual que a fazem progredir enquanto teoria e prática. A obra não se limita a esse percurso histórico, há também uma importante contribuição de terminologias, etimologias, que mostram um amplo conhecimento linguístico, literário e cultural, com posicionamentos críticos, inclusive acerca de política linguística, tal como o momento em que o autor crítica claramente a resistência dos franceses frente aos estrangeirismos de modo geral e como isso afetou as traduções da obra de Freud para o francês.

O texto de TAVARES (2011) não é somente um debate em torno da tradução de Freud, mas uma crítica precisa e rigorosa diante da complexidade que é a Psicanálise. Para mim, a obra traz à tona, através da tradução, todo o debate, que não é pequeno no meio psicanalítico, em torno da transmissão em psicanálise, o que paradoxalmente não é 
Maliska, M. E. - Do (in)traduzível (resenha)

possível de se alcançar inteiramente pela própria tradução. Em outras palavras, por mais adequada que possa ser uma tradução de Freud ela não dá inteiramente conta da discursividade sobre o inconsciente que ele inaugura, pois o inconsciente só mostra seus verdadeiros efeitos em uma análise. Isso é efetivamente passível de uma transmissão, no divã, no exercício mesmo da psicanálise, e não em uma tradução. Isso toca num ponto intraduzível da Psicanálise, esse ponto que a língua não alcança enquanto simbolização, na medida em que numa análise entra em cena um real da língua, algo que a própria língua, enquanto simbolização, não alcança.

As tentativas de tradução da obra de Freud parecem que, de certo modo, sempre estarão imersas em um impossível: colocar a clínica e o ato inaugurar do inconsciente em outras palavras. Há algo que é da própria clínica e que as palavras não dão conta, é o que faz LACAN (2008) preferir, no Seminário 16, um discurso sem palavras. Um discurso que se passa na experiência clínica com o inconsciente, em que as palavras, apesar de serem necessárias, são insuficientes. Diante disso parece louvável e trágico o trabalho do tradutor/ "traidor" que busca não somente na tradução, mas na transposição, na translinguisticidade colocar Freud em palavras.

O gesto de TAVARES (2011) é particularmente ousado e surpreendente, pois ele consegue avaliar as traduções e tecer comentários que levam em conta aspectos técnicos, conceituais e teóricos da Psicanálise por um lado, e aspectos literários e relativos às teorias da tradução por outro. Sem tomar um posicionamento tendencioso frente às recentes traduções brasileiras, o autor não deixa de mostrar sutilmente a sua preferência e a sua posição em relação às traduções. Desse modo, o texto não é tendencioso, mas também não é isento de posicionamentos, como se buscasse uma suposta neutralidade, na medida em que é possível depreender a posição do autor e a sua crítica face às traduções de Freud. 